\title{
Increased frequency of severe diabetic ketoacidosis at type 1 diabetes onset among children during COVID-19 pandemic lockdown: an observational cohort study \\ Zwiększona częstość występowania ciężkiej cukrzycowej kwasicy ketonowej u dzieci z cukrzycą typu 1 w czasie pandemii COVID-19 - kohortowe badanie obserwacyjne
}

\author{
${ }^{1}$ Katarzyna Dżygało, ${ }^{2}$ ędrzej Nowaczyk, ${ }^{1}$ Alicja Szwilling, ${ }^{1}$ Agnieszka Kowalska \\ ${ }^{1}$ Clinical Department of Pediatric Diabetology and Pediatrics, UCK WUM DSK, Medical University \\ of Warsaw, Poland \\ ${ }^{2}$ Department of Pediatrics, Medical University of Warsaw, Poland
}

\begin{abstract}
Introduction: On March 11, 2020 the WHO announced a coronavirus disease 2019 (COVID-19) pandemic. Lockdown restrictions, compromised access to medical care and fear of potential exposure to SARS-CoV-2 have forced patients with non-COVID-19 illnesses such as type 1 diabetes (T1D) to stay home. This situation can lead to delay in T1D diagnosis and insulin treatment resulting in rapid progression to diabetic ketoacidosis (DKA) and therefore increased risk of complications and death.

Aim of the study: The aim of this study was to evaluate the frequency and severity of DKA at the onset of T1D in children diagnosed in our department during COVID-19 pandemic lockdown from March 2020 till May 2020 in comparison to corresponding period of the previous year.

Material and methods: We collected data of children with newly diagnosed T1D. DKA was defined according to ISPAD guidelines. Results: The study cohort comprised 34 children in group 2020 and 52 in group 2019 with an average age $9.90 \pm 4.9$ vs. $9.59 \pm 4.7$ years with mean $\mathrm{HbA}_{1 \mathrm{c}} 12.9 \pm 2.4$ vs. $11.5 \pm 2.2 \%$, respectively. The incidence of DKA was higher by $12 \%$ in group 2020 vs. 2019 (52.94\% vs $40.38 \% ; p=0.276$ ). Regarding the DKA severity (2020 vs. 2019) $32.35 \%$ vs. $11.54 \%$ were severe $(p=0.026), 17.65$ vs. $13 \%$ were moderate $(p=0.759)$, and 2.94 vs. $15.38 \%$ were mild $(p=0.081)$. None of the analyzed patients were COVID-19 positive.

Conclusions: During the COVID-19 pandemic lockdown changes in society and health care system, the DKA rate has increased by 12 percentage points with more severe cases noted in children with newly diagnosed T1D. Regular education of the whole society about the symptoms of diabetes could contribute to faster diagnosis of T1D and reduction of DKA prevalence.
\end{abstract}

Key words:

children, diabetes mellitus type 1, diabetic ketoacidosis, COVID-19.

\section{Streszczenie}

Wprowadzenie: Ogłoszona przez WHO w marcu 2020 r. pandemia choroby koronawirusowej 2019 (COVID-19) wpłynęła na wiele aspektów naszego życia. Aktualna sytuacja epidemiologiczna może mieć dodatkowy wpływ na pogłębienie problemów z rozpoznawaniem cukrzycy typu 1 (T1D) i opóźnienie rozpoczęcia leczenia, a w konsekwencji zwiększenia ryzyka rozwoju cukrzycowej kwasicy ketonowej (DKA).

Cel pracy: Ocena i porównanie ciężkości i częstości występowania DKA w okresie od marca do maja 2019 r. oraz w czasie epidemii COVID-19 od marca do maja 2020 r. w grupie dzieci z nowo rozpoznaną cukrzycą.

Materiał i metody: Dokonano analizy przypadków nowo rozpoznanej T1D u dzieci hospitalizowanych na naszym oddziale w analogicznych okresach. Ciężkość DKA była określona w oparciu o definicję ISPAD.

Wyniki: Analizą objęto łącznie 86 dzieci: 34 w grupie z 2020 r. i 52 w grupie z 2019 r. odpowiednio w średnim wieku 9,90 $\pm 4,9$ vs 9,59 $\pm 4,7$ lat ze średnią $\mathrm{HbA}_{1 \mathrm{c}}$ odpowiednio $12,9 \pm 2,4$ vs $11,5 \pm 2,2 \%$.

W badanym okresie 2020 r. częstość DKA była o 12 punktów procentowych większa w porównaniu z poprzednim rokiem (52,94\% vs $40,38 \% ; p=0,276)$.

Przy przyjęciu (2020 vs 2019) 32,35\% vs 11,54\% przypadków spełniało kryteria ciężkiej DKA ( $p=0,026)$, 17,65 vs 13\% umiarkowanej ( $p=0,759)$ i 2,94 vs 15,38\% łagodnej $(p=0,081)$.

U żadnego z analizowanych pacjentów nie rozpoznano COVID-19. 
Wnioski: Związana z pandemią COVID-19 zmiana w funkcjonowaniu społeczeństwa i opieki zdrowotnej wpłynęła na wzrost częstości DKA w przebiegu nowo rozpoznanej cukrzycy typu 1 u dzieci o 12 punktów procentowych wraz ze zwiększeniem odsetka ciężkich przypadków. Regularna edukacja całego społeczeństwa o objawach cukrzycy mogłaby wpłynąć na szybsze rozpoznawanie choroby i redukcję częstości DKA.

Słowa kluczowe:

dzieci, cukrzyca typu 1, cukrzycowa kwasica ketonowa, COVID-19.

\section{Introduction}

Coronavirus disease 2019 (COVID-19) caused by severe acute respiratory syndrome coronavirus 2 (SARS-CoV-2), was first reported in December 2019 in Wuhan City, China [1]. On the $11^{\text {th }}$ of March 2020 the WHO announced a COVID-19 pandemic known as coronavirus pandemic [1]. It has affected many aspects of our lives. Most of the countries has initiated a range of public health care interventions and government regulations to mitigate the transmission of SARS-CoV-2. On the $4^{\text {th }}$ of March, Poland reported the first laboratory-confirmed COVID-19 case [2]. On March 13, a state of epidemic emergency and on March 20, a state of epidemic was announced in Poland, which resulted in social distancing and has strong impact on reorganization of public health system with the obligation to keep social distancing and the recommendation to stay at home [3]. According to the recommendations, telephone contact became preferred form of medical consultation [4]. Traditional personal visits were possible only if absolutely necessary. Direct contact with physician has become significantly limited. Moreover, according to the recommendations, patients with mild symptoms suggesting common cold were advised to stay home [4]. Eventually, to reduce the impact of the COVID-19 outbreak on healthcare systems, redistribution of healthcare resources to the COVID-19 response was implemented [5]. All these factors have resulted in unintentional disregard of non-COVID-19 care for other diseases such as type 1 diabetes (T1D).

The signs and symptoms of T1D in children usually develop quickly. The presence of diabetic ketoacidosis (DKA) is predominantly a consequence of delayed diagnosis and initiation of insulin therapy [6]. Our previous clinical experience shows that common symptoms of diabetes such as weight loss, fatigue, polyuria, nycturia, Kussmaul breathing, vomiting and other symptoms may be misdiagnosed with for i.e. pharyngitis, flu or another common virus, pneumonia, eating disorders food poisoning or urinary tract infection. These may result in delayed T1D diagnosis and, in turn, rapid progression to diabetic ketoacidosis (DKA) and therefore increased risk of complications and death. According to literature, between 14.7 and $79.8 \%$ of subjects with newly diagnosed T1D present in DKA, which has a $0.15-0.35 \%$ mortality at onset [7]. Recent studies suggest that DKA at diagnosis has been associated with less residual cell function and poorer prognosis of long-term glycemic control, independent of other factors [8-11]. We hypothesized that the current epidemiological situation could worsen the already existing difficulties in T1D diagnosis in children and lead to further delay in insulin treatment. However, to date, there is limited evidence supporting our hypothesis.
The aim of this study was to evaluate the frequency and severity of DKA at the onset of T1D in children admitted to our center during COVID-19 pandemic lockdown from March 2020 till May 2020 in comparison to corresponding period of the previous year.

\section{Material and methods}

This cohort study was performed among all children aged 0 to 18 years with newly diagnosed T1D in our department. The data from two periods: between March to May 2020 and corresponding period in year 2019 were compared. Data were collected from paper or electronic documentation, retrospectively.

Diabetes diagnosis was based upon WHO criteria. Diabetes onset was defined as date of T1D diagnosis. We excluded children with prediabetes, non-T1D or diabetes diagnosed and treated at other medical care site. Data were manually reviewed and extracted from medical files (laboratory results and clinical documentation) of each patient and included age, sex, weight, height, BMI z-score at diabetes onset, date of diabetes onset, patient's pathway to diagnosis, family history of T1D in first- and/ or second-degree relatives and information about symptoms reported during the days preceding the overt T1D diagnosis and their duration. Children were analyzed also with regard to the timing of presentation (whether or not there was a delay in initial diagnosis) and referral patterns. A "delay in diagnosis" was defined as a patient with newly diagnosed T1D who have a limited medical contact or was not sent for immediate further evaluation within 24 hours. Primary care referral was confirmed by analyzing of the clinical records or referral letter, if available. Primary care included both general practice and night medical assistance. Self-presentation was defined as visit to secondary care at a hospital emergency department without a referral. Health care professional contact $(\mathrm{HCPC})$ was defined as any contact with physician in the previous 4 weeks not leading to T1D diagnosis. Health care professional contact was established by review of the clinical notes and records. Clinical symptoms and signs observed in this study included polydipsia, polyuria, nycturia, weight loss and weakness (all observed at nominal scale: Yes/No). We collected also levels of initial: capillary $\mathrm{pH}, \mathrm{HCO}_{3}^{-}$, blood glucose, osmolality, $\beta$-hydroksybutyrate (3HB), sodium, $\mathrm{HbA}_{1 \mathrm{c}}$. $3 \mathrm{HB}$ serum levels were tested on a fingerstick blood specimen by a hand-held device (Optium Xido, Abbott). The levels of 3HB hereinafter was referred as ketones. As initial laboratory data for sodium, serum osmolality and blood ketones were not routinely available for children not presented with DKA, these outcomes were analyzed only in DKA subgroups. 
Our primary outcome was DKA at the time of a diabetes diagnosis. The secondary outcome was the severity of DKA (mild, moderate, severe) classified according to ISPAD guidelines [6]. Mild DKA was defined as $\mathrm{pH}<7.30$ or bicarbonate $<15 \mathrm{mmol} / \mathrm{l}$, moderate as $\mathrm{pH}<7.20$ or bicarbonate $<10 \mathrm{mmol} / \mathrm{l}$ and severe DKA as $\mathrm{pH}<7.10$ or bicarbonate $<5 \mathrm{mmol} / \mathrm{l}$. According to the obtained results, children were divided into two subgroups: non DKA and DKA group.

To minimize the risk of bias, we based on hospital documentation and laboratory findings coming from our hospital. Created data tables were double-checked with original documentation by other, independent person. On the newly diagnosed patient admission the detailed history, measurements, along with routine set of laboratory tests are taken. Therefore, we can assume that high quality, comparable and reliable data were collected.

Statistical analysis was performed using GraphPad Prism 6.00 (GraphPad Software, La Jolla California USA). Descriptive statistics [mean and standard deviation (SD) for continuous (quantitative) variables and frequencies (\%) and numbers (n) for categorical variables] were calculated. The assumption that the data were sampled from a population following Gaussian distributions was tested using Shapiro-Wilk normality test. If the data were normally distributed a two-tailed unpaired T-test was used to compare continuous variables between groups. A nonparametric Mann-Whitney U-Test was performed to compare results between groups for not-normally distributed data. Fisher exact test or Chi-square tests of association were applied to assess if any differences exist between each categorical factor and each binary outcome. Results are presented as mean values with standard deviations (SD). $P$-values less than 0.05 were considered as significant.

\section{Results}

Total of 550 patients were examined for eligibility. Out of 142 patients hospitalized in March-May 2020 and 408 patients in March-May 2019, 356 were excluded due to not meeting diabetes onset criterium and 108 were not T1D. Finally, we included 34 children (35.3\% girls) in group 2020 and 52 children (50\% girls) in group 2019. No differences in terms of age, sex and BMI Z-score between 2019 and 2020 groups were found. Detailed characteristics of included patients is shown in Table I. None of the patients or their caregivers were diagnosed with COVID-19. The most common symptoms at presentation were polyuria and polydipsia, which were seen in more than $90 \%$ of patients. Loss of weight was significantly more prominent in group $2020(p=0.0006)$. In about $17 \%$ patients weight loss was unclear and difficult to estimate. Capillary blood test for $3 \mathrm{HB}$ were not routinely performed therefore the data were not available for 13 (38.2\%) cases in 2020 and 29 (55.7\%) cases in 2019. In particular, 3 HB was analyzed neither in patients presented with mild or non-DKA symptoms, nor with severe DKA treated initially in the ICU Unit. Results are shown in Table I.

We observed an increased DKA incidence of more than 12 percentage points in group 2020 in comparison to group
2019. Overall, $52.94 \%$ vs. $40.38 \%$ of the patients in group 2020 and 2019 presented with DKA at T1D diagnosis, although the difference was not remarkably significant $(p=0.276)$. There was a strong tendency towards statistically significant difference in initial $\mathrm{pH}$ values $(p=0.054)$.

We found significant differences between groups in terms of DKA severity. There was 11/34 (32.35\%) severe DKA cases noted in group 2020 and 6/52 (11.54\%) in group 2019 $(p=0.0262)$. In group $202017.65 \%$ (6/34) and in group 2019 $13.46 \%(7 / 52)$ of children had moderate DKA $(p=0.759)$. In group 2020 2.94\% (1/34) and in group 2019 - 15.38\% (8/52) of children had mild DKA $(p=0.081)$. Results are shown in Figure 1. Significantly more severe DKA cases were observed in group 2020. In DKA 2020 vs. 2019 subgroups, 61.1\% vs. $28.6 \%$ were severe, 33.3 vs. $33.3 \%$ were moderate, and 5.6 vs. $38.1 \%$ were mild. The number of new T1D cases per month did not vary between groups, except in March (5 cases in group 2020 and 23 cases in group 2019; Table II). Type 1 diabetes occurred in $6(17.65 \%)$ first- or second-degree relatives of the study participants in group 2020 and in 7 (13.46\%) in group 2019 ( $p=0.759)$

We noted a significantly higher proportion $(21 / 32,65.6 \%)$ of patients who self-presented to the hospital in year 2020 in comparison to year $2019(6 / 52,11.5 \%), p<0.0001$. The majority of children in group 2019 presenting with T1D onset were referred from primary care (88.5\%) and were in DKA in 19/46 cases (41.3\%). In group 2020, 21 of 34 (61.67\%) patients and their caregivers originally came directly to hospital emergency unit on their own initiative (self-presented). Among analyzed patients, 10 (29.41\%) in group 2020 and 17 (32.69\%) in group 2019 had at least one previous HCPc, with no differences between groups.

\section{Discussion}

To our knowledge, this is the first study to evaluate and compare the frequency and severity of DKA at the onset of T1D in children diagnosed during COVID-19 pandemic lockdown in comparison to previous year. The major findings of this study were a high prevalence of children presenting with DKA at diagnosis along with initially upward trend in DKA severity at diagnosis of type 1 diabetes during COVID-19 pandemic lockdown. Undoubtedly, the 3-month rate and severity of DKA at T1D onset in our center during COVID-19 pandemic lockdown was unacceptably high (52.94\%) and current epidemiological situation worsen the already existing problem resulting in clinically important increase in DKA rate by $12 \%$ and statistically significant increase in proportion of severe and moderate DKA cases. Paradoxically, the rise in DKA at T1D onset may not be only driven by COVID-19 lockdown. In the light of existing reports on DKA rate, our results from selected period in year 2019, before COVID-19 crisis, are also alarmingly high (40.38\%) and, what should be emphasized, the difference between analyzed periods were not statistically significant. An increasing prevalence of T1D has been noted in Polish children [13]. 
Table I. Demographic, clinical and biochemical characteristics of analyzed patients

\begin{tabular}{|c|c|c|c|}
\hline Parameter & Group 2020 & Group 2019 & $p$ value \\
\hline Number of patients $(n)$ & 34 & 52 & \\
\hline $\operatorname{Sex}(F / M)$ & $12 / 22$ & $26 / 26$ & 0.192 \\
\hline Age at diagnosis (years) & $9.90 \pm 4.9(0.8-17.8)$ & $9.59 \pm 4.7(1.4-17.3)$ & 0.822 \\
\hline $\mathrm{HbA}_{1 \mathrm{c}}(\%)$ & $12.9 \pm 2.4 \%(6.8-17.6)$ & $11.5 \pm 2.2 \%(7.6-15.7)$ & $0.011^{*}$ \\
\hline BMI z-score & $-0.36 \pm 1.5$ (from -2.29 to 3.30 ) & $-0.31 \pm 1.5$ (from -3.14 to 4.28 ) & 0.680 \\
\hline Insulin requirement $(\mu / \mathrm{kg} / \mathrm{d})$ & $0.75 \pm 0.3(0.2-1.3)$ & $0.57 \pm 0.3(0.2-1.4)$ & $0.021 *$ \\
\hline Vitamin $D_{3}(\mathrm{ng} / \mathrm{ml})$ & $22.00 \pm 9.94(4.2-56.3)$ & $20.36 \pm 9.94(7.1-62)$ & 0.276 \\
\hline Family history $(n)$ & $6(17.65 \%)$ & $7(13.46 \%)$ & 0.759 \\
\hline Referral/self-presented $(n)$ & $13 / 21$ & $46 / 6$ & $<0.000^{*}$ \\
\hline Previous HCP contact (HCPC) (n) & $10(29.4 \%)$ & $17(32.7 \%)$ & 0.815 \\
\hline Diagnosis delay > $24 \mathrm{~h}(n)$ & $11(32.4 \%)$ & $14(26.9 \%)$ & 0.632 \\
\hline Duration of symptoms (weeks) & $3.09 \pm 2.6(0.5-12)$ & $3.69 \pm 3.43(0-12)$ & 0.631 \\
\hline Polyuria & $33(97.1 \%)$ & $47(90.4 \%)$ & \\
\hline Polydipsia & $34(100 \%)$ & $48(92.3 \%)$ & \\
\hline Nycturia or bedwetting & $15(44.1 \%)$ & $22(42.3 \%)$ & \\
\hline Weakness & $14(41.2 \%)$ & $25(48.1 \%)$ & \\
\hline Weight loss & $30(88.2 \%)$ & $37(71.2 \%)$ & \\
\hline Weight loss (kg) & $5.11 \pm 4.0(0-14)$ & $2.12 \pm 2.28(0-9)$ & $0.001 *$ \\
\hline Glucose level (mg/dl) & $463.5 \pm 159.2(237-839)$ & $428.7 \pm 152.7(213-757)$ & 0.315 \\
\hline $\mathrm{pH}$ & $7.20 \pm 0.18(6.81-7.43)$ & $7.28 \pm 0.14(6.84-7.49)$ & 0.054 \\
\hline Bicarbonate (mmol/l) & $13.57 \pm 9.21(2.0-29.2)$ & $17.00 \pm 7.67(3.7-28.4)$ & 0.074 \\
\hline Blood Ketones (mmol/l) & $4.88 \pm 1.52(0.9-6.9)$ & $5.17 \pm 2.52(0.0-7.5)$ & $0.039 *$ \\
\hline Missing ketones data & $13 / 34(38.2 \%)$ & $23 / 52(55.8 \%)$ & \\
\hline DKA at presentation $(n)$ & $18(52.94 \%)$ & $29(40.38 \%)$ & 0.276 \\
\hline Only severe DKA (n) & $11(32.35 \%)$ & $6(11.53 \%)$ & $0.026^{\star}$ \\
\hline Both moderate or severe DKA & $17(50 \%)$ & $13(25 \%)$ & $0.022 *$ \\
\hline Osmolality $\left(\mathrm{mOsm} / \mathrm{kg} \mathrm{H}_{2} \mathrm{O}\right)$ & $305 \pm 19.4(289-363)$ & $284 \pm 12.8(282-332)$ & 0.063 \\
\hline $\mathrm{Na}(\mathrm{mmol} / \mathrm{l})$ & $139 \pm 7.1(127-160)$ & $136 \pm 5.6(129-151)$ & 0.134 \\
\hline Corrected $\mathrm{Na}(\mathrm{mmol} / \mathrm{l})$ & $145 \pm 8.4(136-171)$ & $142 \pm 8.4(135-158)$ & 0.060 \\
\hline
\end{tabular}

Blood ketones - $\beta$-hydroksybutyrate; data reported as mean $\pm \mathrm{SD}$ 

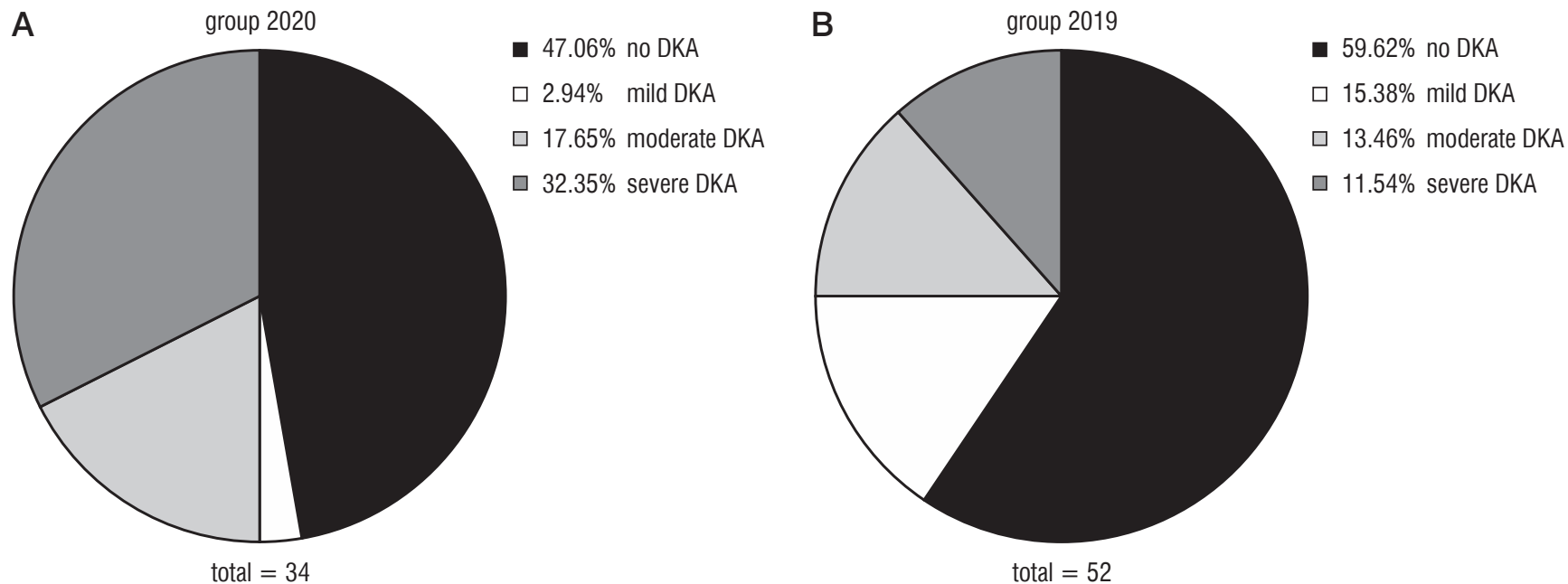

Figure 1. Proportion of patients in terms of DKA severity in group 2020 (A) and in group 2019 (B)

Table II. Overall (3-month) and monthly prevalence and severity of DKA in both groups

\begin{tabular}{|c|c|c|c|c|c|c|c|c|}
\hline & \multicolumn{2}{|l|}{ Overall } & \multicolumn{6}{|l|}{ Monthly } \\
\hline & All 2020 & All 2019 & March 2020 & March 2019 & April 2020 & April 2019 & May 2020 & May 2019 \\
\hline \multirow{2}{*}{$\begin{array}{l}\text { Total number } \\
\text { of patients (F/M) }\end{array}$} & 34 & 52 & 5 & 23 & 15 & 15 & 14 & 14 \\
\hline & $12 / 22$ & $26 / 26$ & $2 / 3$ & $12 / 11$ & $5 / 10$ & $9 / 6$ & $5 / 9$ & $5 / 9$ \\
\hline \multirow[t]{2}{*}{ All DKA } & 18 & 21 & 3 & 12 & 10 & 5 & 5 & 4 \\
\hline & (52.94\%) & (40.38\%) & $(60.0 \%)$ & (52.2\%) & (66.7\%) & (33.3\%) & (35.7\%) & (28.6\%) \\
\hline \multirow[t]{3}{*}{ No DKA } & 16 & 31 & 2 & 11 & 5 & 10 & 9 & 10 \\
\hline & (47.06\%) & (59.62\%) & $(40.0 \%)$ & $(47.8 \%)$ & $(33.3 \%)$ & $(66.7 \%)$ & $(64.3 \%)$ & $(71.4 \%)$ \\
\hline & \multicolumn{2}{|l|}{$p=0.276$} & \multicolumn{2}{|l|}{$p=1.000$} & \multicolumn{2}{|l|}{$p=0.1431$} & \multicolumn{2}{|l|}{$p=1.000$} \\
\hline \multirow[t]{3}{*}{ Mild DKA } & 1 & 8 & 0 & 5 & 1 & 3 & 0 & 0 \\
\hline & (2.94\%) & (15.38\%) & $(0.0 \%)$ & (21.7\%) & $(6.7 \%)$ & (20.0\%) & $(0.0 \%)$ & $(0.0 \%)$ \\
\hline & \multicolumn{2}{|l|}{$p=0.081$} & \multicolumn{2}{|l|}{$p=0.550$} & \multicolumn{2}{|l|}{$p=0.597$} & \multicolumn{2}{|l|}{$p=1.000$} \\
\hline \multirow{3}{*}{ Moderate DKA } & 6 & 7 & 0 & 4 & 4 & 0 & 2 & 3 \\
\hline & (17.65\%) & (13.46\%) & $(0.0 \%)$ & (17.4\%) & (26.7\%) & $(0.0 \%)$ & $(14.3 \%)$ & $(21.4 \%)$ \\
\hline & \multicolumn{2}{|l|}{$p=0.759$} & \multicolumn{2}{|l|}{$p=0.568$} & \multicolumn{2}{|l|}{$p=0.996$} & \multicolumn{2}{|l|}{$p=1.000$} \\
\hline \multirow[t]{3}{*}{ Severe DKA } & 11 & 6 & 3 & 3 & 5 & 2 & 3 & 1 \\
\hline & (32.35\%) & (11.54\%) & (60.0\%) & (13.0\%) & (33.3\%) & (13.3\%) & $(21.4 \%)$ & (7.1\%) \\
\hline & \multicolumn{2}{|l|}{$p=0.026^{\star}$} & \multicolumn{2}{|l|}{$p=0.050$} & \multicolumn{2}{|l|}{$p=0.340$} & \multicolumn{2}{|l|}{$p=0.596$} \\
\hline
\end{tabular}

\footnotetext{
$\mathrm{F}$ - female; $\mathrm{M}$ - male
} 
In previous years, DKA 12-month prevalence in our center was noticeably lower, and varied from 25 to $28 \%$, without differences between the periods from 2006 to 2007 and from 2013 to 2014 [6], similar to the DKA prevalence among children in the area of eastern and central Poland (which cover around 35\% of the Polish population) [14]. In another regions of Poland, the incidence of DKA at diagnosis of T1D was about 22-26\%, although did not exceed 36\% [15-17]. Therefore, based on these findings, we may conclude that in comparison to recent years, DKA incidence in our center during 3 months of pandemic state has roughly doubled. Only few studies in pediatric population report on DKA prevalence of more than 50\% [18, 19]. World widely, the prevalence of DKA at T1D onset widely varies by country and region and in overall is estimated to be $29.2 \%$ (95\% Cl: 28.82, 29.56) $[20,21]$. Our findings showed an upward trend in the severity of DKA. Comparing the proportion of DKA severity in year 2019 with our previous report, a shift between mild and moderate DKA is noticeable, in favor of moderate cases. The frequency of severe DKA remained constant at a level of approximately $28-30 \%$ of all DKA cases [13]. This is consistent with previous observations from other Polish centers, with severe DKA rate at the level between 24\% (Greater Poland) [16], and 31.4\% (Lesser Poland) [15]. Global statistics on severe DKA incidence vary between 22 to 37\% [22-25]. One fourth of healthcare professionals reported delays in diagnosis and an increased rate of DKA in large global survey during COVID-19 pandemic [12]. What should be emphasize, throughout the COVID-19 pandemic lockdown, severe DKA rate at T1D onset dramatically raised and exceeded $60 \%$ of all DKA cases. Overall, children with newly diagnosed T1D were more likely to present with moderate or severe DKA. This is an alarming result, due to reports of the impact of severe and moderate DKA at T1D onset, on worse cognitive score and altered brain growth [26]. The question arises whether the observed further increase in the severity of DKA results exclusively from public health system lockdown during a pandemic. In terms of clinical parameters describing DKA, regardless of strong tendency, no significant difference for $\mathrm{pH}$ values between 2019 and 2020 was found, although power of the study, calculated post hoc for this outcome, appeared to be only $59.2 \%$. Similarly, the results for $3 \mathrm{HB}$ are burdened with a large proportion of missing data, hence their interpretation in the context of the severity of ketosis is not possible.Although, we did not perform any analysis to evaluate factors influencing frequency and severity of DKA as it was not the aim of this research, there are a few possible factors contributing to observed persistence of high DKA prevalence. Even though, T1D is one of the most common chronic disease in children, reducing the rate of DKA at T1D onset is still challenging and neglect of typical symptoms resulting in misdiagnosis may play a key role in delay of insulin treatment, thereby increasing the risk of DKA three times [27-29]. As many children presenting with DKA have had a contact with a health care professional before diagnosis [29], we may have expected the overall DKA rate to increase due to limited medical access and greater delay in diagnosis during COVID-19 pandemic but it was not the case. In literature findings on duration of symptoms and DKA are inconsistent. Study by Neu et al. showed that children with DKA had a shorter duration of symptoms than those without DKA [30]. These findings would support the presumption of DKA development rather as a result of a particularly aggressive disease rather than missed or delayed diagnosis. In contrast, Usher-Smith et al. report similar mean duration of symptoms in children presenting with or without DKA [28]. On the other hand, we even noticed not significantly shorter duration of symptoms in group 2020. Several studies indicate that DKA is associated with higher levels of $\mathrm{HbA}_{1 \mathrm{c}^{*}}$. Our group 2020 had significantly higher $\mathrm{HbA}_{1 \mathrm{c}}$ levels at diagnosis.

Both primary care physicians and parents play a crucial role in the prevention of DKA [31]. Moreover, we observed that in group 2020 significantly more patients self-presented with T1D symptoms directly to the hospital bypassing the diagnostic step in primary care. We expected the sudden and significant decrease in HCPC during COVID-19 pandemic. Surprisingly, we did not find difference in previous $\mathrm{HCP}$ in last month before diagnosis between groups. We found that about one-third of children had a previous contact with a health care professional. Despite the comparable number of HCPc, only one-third of patients with T1D onset in 2020 were referred from primary care. In contrast to 2020, the majority of children in 2019 were referred from primary care. However, we did not collect data on type of HCPc (personal or digital contact). Based on our experience, we can only assume that vast majority of HCPc were digital in analyzed period of 2020. Medical digital consultations were uncommon up to nowadays. COVID-19 crisis accelerated so-called Health Care's Digital Revolution. Doubtless, the quality of medical contacts worsens with digital contact as the new form of medical consultation. HCP could only base on the selective information provided by parent by telephone contact and misinterpret it as their attention could be directed predominantly towards SARS-CoV-2 infection symptoms.

A positive family history of diabetes is one of the protective factors associated with a reduced risk of DKA [28, 32]. In contrary, first-degree relative with T1D did not affect DKA occurrence in study by Niechciał et al. [16]. Our research did not reveal a significant difference in family history between groups, therefore we did not perform sub analysis on the its correlation with incidence or severity of DKA. We noticed that nearly the same number of patients had first- or second-degree relative with T1D.

It is well known that the risk of DKA increases significantly when diabetes is not diagnosed promptly and increased T1D awareness and higher parental education as a protective factor in preventing DKA was highlighted in previous publications [28]. The high incidence of severe and moderate DKA at T1D initial presentation during COVID-19 crisis may be escalated due to parents' unawareness of classic symptoms of hyperglycemia, which gained importance in the view of lockdown restrictions. We did not have details on type of previous HCPc in our group, although it can be assumed that despite the fact that there was no significant difference in overall number of medical contacts between both analyzed groups, those medical consultation performed in year 2020 were of different quality as they were probably predominantly digital contacts. 
Our data support the need for improvement of awareness regarding the symptoms of T1D and its prevalence in children among both medical professionals' and general public and/ or for screening programs for T1D. Literature suggests that increased awareness of T1D results in earlier diagnosis and treatment, can lead to DKA rate decrease [8, 33-35]. However, awareness publicity campaigns directed to type 1 diabetes have not shown consistent results [24, 33, 34, 36-39].

Partially, high DKA rate can be explained by the increase in the proportion of the youngest children, who statistically more often develop DKA during T1D onset [21, 22, 35]. It is reported that young children present with a shorter duration of symptoms and more rapid T1D progression. However, in our center percentage of patients under 5 years of age with T1D onset in last two years did not differ (data not shown).

The main strength of our study is that we collected a representative number of patients over designated period. We based on patients' documentation created exclusively in our department, according to our preestablished standards. Laboratory tests were performed in our hospital laboratory only. Data on DKA presence and severity were available for all analyzed cases. Selection criteria was clearly defined. We also have analyzed the total number of included patients, without exclusions therefore we do not expect the selection bias in the analysis.

Nonetheless, there are limitations to this study, predominantly methodological issues related to study observational design. As a retrospective nature of our study, it is prone to missing data and limited by completeness of medical records and accuracy of patients' medical history report given by parents or caregivers. When interpreting the study results, it should be borne in mind that data concerning medical history such as diagnosis delay, previous $\mathrm{HCPc}$, type of $\mathrm{HCPc}$, family history or mode of presentation may not be complete. Parents could unintentionally forget to report some important information. Therefore, it is likely that data form medical history may be incomplete. Likewise, the test of $3 \mathrm{HB}$, is not routinely performed, therefore we were unable to collect enough data for analysis. Our study was also limited to one diabetic tertiary center. Our

\section{References}

1. WHO. World Health Organization. Timeline of WHO's response to the pandemic from 31 December 2019. [Internet]. 2020 [cited 2020 Jun 1]. Available from: https://www.who.int/emergencies/diseases/ novel-coronavirus-2019/events-as-they-happen

2. MZ. Ministerstwo Zdrowia. [Pierwszy przypadek koronawirusa w Polsce.] [Internet]. 2020. [cited 2020 Jun 1]. Available from: https://www.gov.pl/web/zdrowie/pierwszy-przypadek-koronawirusaw-polsce

3. MZ. Ministerstwo Zdrowia. [Wprowadzamy stan epidemii w Polsce.] [Internet]. 2020. Available from: https://www.gov.pl/web/koronawirus/wprowadzamy-stan-epidemii-w-polsce

4. NFZ. Narodowy Fundusz Zdrowia. [Teleporady dotyczące koronawirusa w przychodniach i w Ambulatoryjnej Opiece Specjalistycz- hospital is one of the largest centers for pediatric diabetes in Poland located in Mazovia province, inhabited by $14.12 \%$ of the Polish population. Predominantly, patients from the Masovian voivodeship aged 0-18 years, with newly diagnosed diabetes, including severe DKA are referred to our university hospital thus probably provides a generalizable representation of DKA rates at diagnosis across Masovian voivodeship.

\section{Conclusions}

Lockdown restrictions, compromised access to medical care and fear of potential exposure to SARS-CoV-2 have forced patients with other non-COVID-19 illnesses, such as new onset T1D to stay home until their illness worsens, sometimes to lifethreatening state.

Our results showed that DKA rate in children admitted to our center with newly diagnosed T1D is high despite its prominent symptoms. In this study we have demonstrated increasing rate and severity of DKA at onset of T1D coinciding with COVID-19 pandemic. It has important implications for clinicians in both primary and secondary care, as well as for children who develop T1D and their parents. Our findings and the experience gained during the COVID-19 lockdown underscore the need to enhance physician and public awareness focusing on the signs and symptoms of T1D and need to consider diabetes as a possible diagnosis in those with nonspecific illness with referring a child immediately, ideally before DKA develops, especially in current epidemiological situation. Medical health providers should be re-educated and reminded to ask about change in thirst and urination. Considering the limited time for medical consultation, at least leaflets or posters should be visible in the patients' environment. On the basis of these findings, continuous and repeated educational diabetes awareness campaign (both posters and social media posts) conducted in Poland directed at physicians, caregivers and public can be expected to improve health outcomes for diabetic children in polish society and change trends in DKA rates at T1D diagnosis. nej] [Internet]. 2020 [cited 2020 Jun 1]. Available from: https://www. nfz.gov.pl/aktualnosci/aktualnosci-centrali

5. Serwis Rzeczypospolitej Polskiej. [III FILAR: Ochrona zdrowia] [Internet]. 2020 [cited 2020 Jun 1]. Available from: https://www.gov.pl/ web/tarczaantykryzysowa/ochrona-zdrowia

6. Wolfsdorf JI, Glaser N, Agus M, et al. ISPAD Clinical Practice Consensus Guidelines 2018: Diabetic ketoacidosis and the hyperglycemic hyperosmolar state. Pediatr Diabetes 2018; 19 Suppl 27: 155-177. doi: 10.1111/pedi.12701

7. Große J, Hornstein H, Manuwald U, et al. Incidence of Diabetic Ketoacidosis of New-Onset Type 1 Diabetes in Children and Adolescents in Different Countries Correlates with Human Development Index (HDI): An Updated Systematic Review, Meta-Analysis, and Meta-Regression. Horm Metab Res 2018; 50: 209-222. doi: 10.1055/s-0044-102090 
8. Jefferies CA, Nakhla M, Derraik JGB, et al. Preventing Diabetic Ketoacidosis. Pediatr Clin North Am 2015; 62: 857-871. doi: 10.1016/j.pcl.2015.04.002

9. Komulainen J, Lounamaa R, Knip M, et al. Ketoacidosis at the diagnosis of type 1 (insulin dependent) diabetes mellitus is related to poor residual beta cell function. Childhood Diabetes in Finland Study Group. Arch Dis Child 1996; 75: 410-415. doi: 10.1136/ adc. 75.5 .410

10. Mortensen HB, Swift PG, Holl RW, et al. Multinational study in children and adolescents with newly diagnosed type 1 diabetes: association of age, ketoacidosis, HLA status, and autoantibodies on residual beta-cell function and glycemic control 12 months after diagnosis. Pediatr Diabetes 2009; 11: 218-226. doi: 10.1111/j.13995448.2009.00566.x

11. Duca LM, Wang B, Rewers M, et al. Diabetic Ketoacidosis at Diagnosis of Type 1 Diabetes Predicts Poor Long-term Glycemic Control. Diabetes Care 2017; 40: 1249-1255. doi: 10.2337/dc17-0558

12. Elbarbary NS, dos Santos TJ, de Beaufort C, et al. COVID-19 outbreak and pediatric diabetes: Perceptions of health care professionals worldwide. Pediatr Diabetes 2020; 21: 1083-1092. doi: 10.1111/pedi.13084

13. Szypowska A, Ramotowska A, Grzechnik-Gryziak M, et al. High frequency of diabetic ketoacidosis in children with newly diagnosed type 1 diabetes. J Diabetes Res 2016; 2016: 9582793. doi: 10.1155/2016/9582793

14. Szypowska A, Skórka A. The risk factors of ketoacidosis in children with newly diagnosed type 1 diabetes mellitus. Pediatr Diabetes 2011; 12: 302-306. doi: 10.1111/j.1399-5448.2010.00689.x

15. Wojcik M, Sudacka M, Wasyl B, et al. Incidence of type 1 diabetes mellitus during 26 years of observation and prevalence of diabetic ketoacidosis in the later years. Eur J Pediatr 2015; 174: 1319-1324. doi: 10.1007/s00431-015-2537-1

16. Niechciał E, Skowrońska B, Michalak M, et al. Ketoacidosis at diagnosis of type 1 diabetes in children and adolescents from Wielkopolska province in Poland: prevalence, risk factors and clinical presentation. Clin Diabetol 2019; 7: 272-278.

17. Pietrzak I, Mianowska B, Zmysłowska A, et al. Epidemiology and clinical course of diabetic ketoacidosis in children and adolescents with type 1 diabetes mellitus. Pediatr Endocrinol Diabetes Metab 2013; 19: 137-142.

18. Alonso GT, Coakley A, Pyle L, et al. Diabetic Ketoacidosis at Diagnosis of Type 1 Diabetes in Colorado Children, 2010-2017. Diabetes Care 2020; 43: 117-121. doi: 10.2337/dc19-0428

19. Jasem D, Majaliwa ES, Ramaiya K, et al. Incidence, prevalence and clinical manifestations at onset of juvenile diabetes in Tanzania. Diabetes Res Clin Pract 2019; 156: 107817. doi: 10.1016/j. diabres.2019.107817

20. Cherubini V, Grimsmann JM, Åkesson K, et al. Temporal trends in diabetic ketoacidosis at diagnosis of paediatric type 1 diabetes between 2006 and 2016: results from 13 countries in three continents. Diabetologia 2020; 63: 1530-1541. doi: 10.1007/s00125020-05152-1

21. Praveen PA, Hockett CW, Ong TC, et al. Diabetic ketoacidosis at diagnosis among youth with type 1 and type 2 diabetes: Results from SEARCH (United States) and YDR (India) registries. Pediatr Diabetes 2020; pedi.12979. doi: 10.1111/pedi.12979
22. Klingensmith GJ, Tamborlane WV, Wood J, et al. Diabetic Ketoacidosis at Diabetes Onset: Still an All Too Common Threat in Youth. J Pediatr 2013; 162: 330-334. doi: 10.1016/j.jpeds.2012.06.058

23. Khanolkar A, Amin R, Taylor-Robinson D, et al. Diabetic Ketoacidosis Severity at Diagnosis and Glycaemic Control in the First Year of Childhood Onset Type 1 Diabetes - A Longitudinal Cohort Study. Int J Environ Res Public Health 2017; 15: 26. doi: 10.3390/ ijerph15010026

24. Fritsch M, Schober E, Rami-Merhar B, et al. Diabetic Ketoacidosis at Diagnosis in Austrian Children: A Population-Based Analysis, 1989-2011. J Pediatr 2013; 163: 1484-1488. doi: 10.1016/j. jpeds.2013.06.033

25. Gunn ER, Albert BB, Hofman PL, et al. Pathways to reduce diabetic ketoacidosis with new onset type 1 diabetes: Evidence from a regional pediatric diabetes center: Auckland, New Zealand, 2010 to 2014. Pediatr Diabetes 2017; 18: 553-558. doi: 10.1111/ pedi.12456

26. Aye T, Mazaika PK, Mauras N, et al. Impact of Early Diabetic Ketoacidosis on the Developing Brain. Diabetes Care 2019; 42: 443449. doi: $10.2337 / \mathrm{dc} 18-1405$

27. Szypowska A, Dżygało K, Wysocka-Mincewicz M, et al. High incidence of diabetic ketoacidosis at diagnosis of type 1 diabetes among Polish children aged 10-12 and under 5 years of age: A multicenter study. Pediatr Diabetes 2017; 18: 722-728. doi: 10.1111/pedi. 12446

28. Usher-Smith JA, Thompson MJ, Sharp SJ, et al. Factors associated with the presence of diabetic ketoacidosis at diagnosis of diabetes in children and young adults: a systematic review. BMJ 2011; 343: d4092. doi: 10.1136/bmj.d4092

29. Bui H, To T, Stein R, et al. Is Diabetic Ketoacidosis at Disease Onset a Result of Missed Diagnosis? J Pediatr 2010; 156: 472-477. doi: 10.1016/j.jpeds.2009.10.001

30. Neu A, Willasch A, Ehehalt $S$, et al. Ketoacidosis at onset of type 1 diabetes mellitus in children - frequency and clinical presentation. Pediatr Diabetes 2003; 4: 77-81. doi: 10.1034/j.13995448.2003.00007.x

31. de Vries L, Oren L, Lazar L, et al. Factors associated with diabetic ketoacidosis at onset of Type 1 diabetes in children and adolescents. Diabet Med 2013; 30: 1360-1366. doi: 10.1111/dme.12252

32. Stipancic G, Sepec MP, Sabolic LLG, et al. Clinical characteristics at presentation of type 1 diabetes mellitus in children younger than 15 years in Croatia. J Pediatr Endocrinol Metab 2011; 24: 9-10. doi: 10.1515/jpem.2011.231

33. King BR, Howard NJ, Verge CF, et al. A diabetes awareness campaign prevents diabetic ketoacidosis in children at their initial presentation with type 1 diabetes. Pediatr Diabetes. 2012; 13: 647-651. doi: 10.1111/j.1399-5448.2012.00896.x

34. Vanelli M, Chiari G, Ghizzoni L, et al. Effectiveness of a prevention program for diabetic ketoacidosis in children. An 8-year study in schools and private practices. Diabetes Care. 1999; 22: 7-9. doi: 10.2337/diacare.22.1.7

35. Hekkala A, Knip M, Veijola R. Ketoacidosis at Diagnosis of Type 1 Diabetes in Children in Northern Finland: Temporal changes over 20 years. Diabetes Care 2007; 30: 861-866. doi: 10.2337/dc06-2281

36. Al Shaikh A, Farahat F, Saeedi M, et al. Incidence of diabetic ketoacidosis in newly diagnosed type 1 diabetes children in western 
Saudi Arabia: 11-year experience. J Pediatr Endocrinol Metab 2019; 32: 857-862. doi: 10.1515/jpem-2018-0548

37. Derraik JGB, Cutfield WS, Maessen SE, et al. A brief campaign to prevent diabetic ketoacidosis in children newly diagnosed with type 1 diabetes mellitus: The NO-DKA Study. Pediatr Diabetes 2018; 19: 1257-1262. doi: 10.1111/pedi.12722

38. Ahmed AM, Al-Maghamsi M, Al-Harbi AM, et al. Reduced frequency and severity of ketoacidosis at diagnosis of childhood type 1 diabetes in Northwest Saudi Arabia. J Pediatr Endocrinol Metab 2016; 29: 259-264. doi: 10.1515/jpem-2015-0077

39. Lansdown AJ, Barton J, Warner J, et al. Prevalence of ketoacidosis at diagnosis of childhood onset Type 1 diabetes in Wales from 1991 to 2009 and effect of a publicity campaign. Diabet Med 2012; 29: 1506-1509. doi: 10.1111/j.1464-5491.2012.03638 